\title{
Potential Analysis And Optimalize Strategy Of Boarding Home Tax In Banyuwangi District
}

\author{
Yeni Puspita, Galih Wicaksono \\ Program Studi Perpajakan \\ Fakultas Ilmu Sosial dan Ilmu Politik, Universitas Jember, Jl. Kalimantan No. 37, Jember, Jawa Timur \\ E-mail: Yeni.fisip@unej.ac.id

\begin{abstract}
ARTICLE INFO
ABSTRACT

Article history:

Received: $25 / 01 / 2020$

Revised: 01/02/2020

Accepted: 13/02/2020

The purpose of this research is to determine the potential of a boarding house tax and tax revenue optimization strategies boarding house at Banyuwangi Regency. The analytical method uses a quantitative approach to give a questionnaire to the boarding house owner as a taxpayer. Based on information from four sub-districts can be concluded that the total potential of boarding house tax in the Banyuwangi Regency is IDR 717,755,450.00. The strategy needs to be done by the local government to increase boarding house tax revenue are through optimizing the intensification of local tax collection, strengthening the collection process, increasing supervision,

Keywords: increasing administrative efficiency and reducing collection costs. This can

Potential Tax Boarding be done by increasing coordination with related institutions in the region.

House, Strategy The analytical method is used as a quantitative approach to give a questionnaire to the boarding house owner as a taxpayer
\end{abstract}

Copyright (C) 2020 Jurnal Mantik. All rights reserved,

\section{Introduction}

Banyuwangi is one of the regencies in East Java that has economic growth that shows a positive trend, this is because the Banyuwangi Regency has made many innovations in the economic field, especially the creative economy. This increase in economic growth, in addition to the impact of the large number of creative economic actors also the government began to aggressively innovate in the field of tourism that raises local wisdom. This tourism has increased the income of the population in Banyuwangi Regency. The data below shows the economic growth rate of Banyuwangi Regency exceeds the National Economic Growth and Economic Growth of East Java, in 2018 the Economic Growth of Banyuwangi Regency is 5,84\% higher than the National Economic Growth which only reached 5,17\% and East Java Economic Growth is 5,65\% (Badan Pusat Statistik, East Java, 2018). Economic growth is the first process of development of national products. The economy grows when there is an increase in capita output. Economic growth shows an increase in the standard of living of the people. One theory put forward is Kuznet's theory. According to Kuznet's theory, economic growth is a long-term growth in a country to give for its needs. Components of economic growth include population, labor (Sukirno, 2006) 

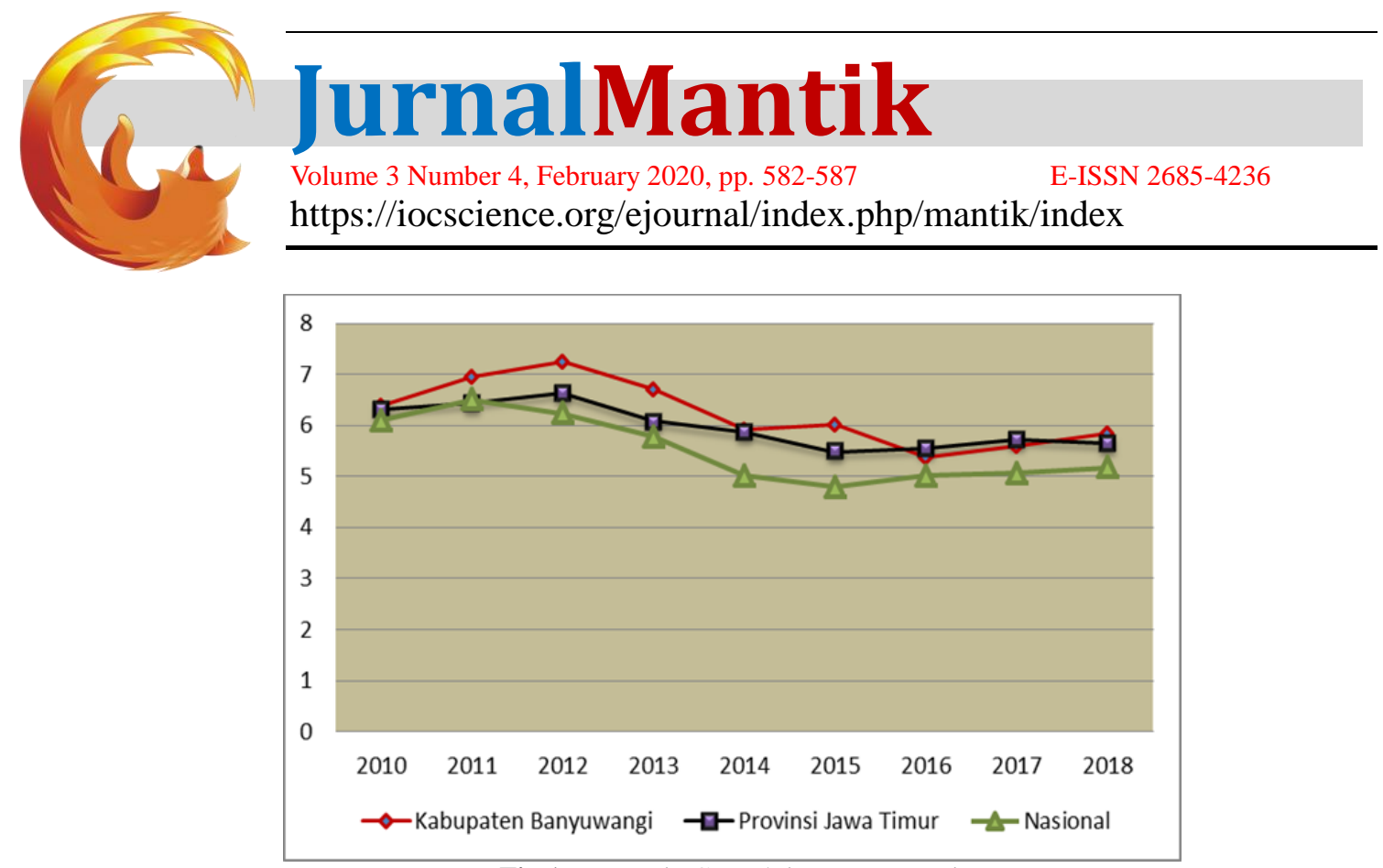

Fig 1.Economic Growth in Banyuwangi

Source: Badan Pusat Statistik, Provinsi Jawa Timur, 2018

Banyuwangi Regency has natural potentials that can be cultivated and developed, thus Banyuwangi Regency will become a district that has superior sectors, such as plantations and fisheries. Even so, other sectors deserve to be looked at, such as the tourism sector, which has recently been often promoted by the government with its programs so that the existing economic growth in Banyuwangi Regency starts to increase rapidly. The impact arising from the existence of this tourism promotion trend. Some other sectors that are also experiencing a positive trend due to the growing development of the tourism sector are the accommodation, food and beverage sector. In 2012 the sector grew by 8,39\%, in 2013 it was 8,07\% and in 2014 it jumped by $10,33 \%$. This tourism sector opens many business opportunities with tourist arrivals, thus impacting homestay income, restaurants, transportation, etc. This will offer income to support the needs of life. The business world also increased can be seen from the surge in passengers at Blimbingsari Banyuwangi Airport which reached 1,308\% from 7,826 passengers in 2011 to 110,234 passengers in 2015. Other tourism supporting sectors such as accommodation, consumption, boards have increased. Based on Badan pusat statistik, the value is around $80 \%$ from IDR 666 billion to IDR 1,19 trillion in 2014. This shows the surge in Gross Regional Domestic Product from IDR 32,46 trillion to IDR 53,37 trillion. Growth is indicated by a decrease in the gap indicator to 0,29 (Badan Pusat Statistik, Banyuwangi Regency, 2019). The existence of the number of Universities in Banyuwangi Regency, both State Universities and Private Universities also has a positive impact on regional revenue, especially boarding tax, where now there are 12 Universities whose interested ones are also never empty each year.

The attractiveness of the Banyuwangi regency sourced from several leading sectors makes the high interest of migrants who come from outside the city to work or to study in Banyuwangi District, This is the background of the implementation of boarding tax in Banyuwangi regency, because one element of local tax revenue is hotel tax which includes boarding tax. Based on Banyuwangi District Regulation Number 2 of 2011 about Regional Taxes is one of the sources of Regional Original Income which has a very strategic role in increasing regional financial capacity and is used for the amount of prosperity of the people. According to Indonesia Law Number 28/2009 about Regional Taxes and regional user fees, the Provincial Region has five types of local taxes, namely: (1) Motorized Vehicle Tax, 2) Motorized Vehicle Transfer Fee, 3) Tax on Motorized Vehicle Fuel, 4) Water Tax Surface, and 5) Cigarette Tax. While there are 11 types of taxes levied by districts / cities, namely: 1) Hotel tax which includes boarding house tax with more than 10 rooms, 2) Restaurant Tax, 3) Entertainment Tax, 4) Billboard Tax, 5) Street Lighting Tax , 6) Non-Metallic Mineral Taxes and Assistance, 7) Parking Taxes, 8) Groundwater Taxes, 9) Swallow Bird Nest Taxes, 10) Rural and Urban Land and Building Taxes, 11) Land and Building Acquisition Fees. 


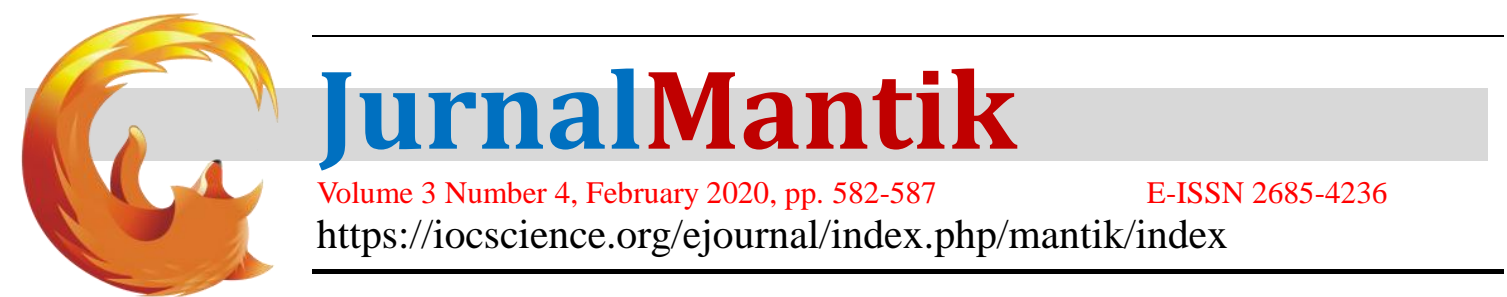

Based on the background above, the authors are interested in raising the potential of boarding tax, because boarding house tax has great potential and can be developed, the formulation of the problem in this study is 1) How the potential of boarding house tax in Banyuwangi Regency, 2) is done to optimize tax revenue boarding house.

\section{Literature Review}

\subsection{Economic growth}

Economic growth is briefly defined as the increase in output per capita in the long term. The emphasis is focused on three aspects, namely the process, an increase in output per capita and in the long term. Economic growth is a process, not an economic picture at a time (one shoot). In the view of the classical economists there are many factors that affect economic growth such as population, the number of stocks of capital, land area and natural resources, as well as the level of teknologi.24 However, in this classical theory, the economists put population growth affects the economic growth. Economists view that additional results are diminishing will affect economic growth,

\subsection{Local tax}

According Mardiasmo (2011) Local Tax is a unit of community had the territorial boundaries of the authority to regulate and administer governmental affairs and public interests own initiative based on the aspirations of the people in the system of the Republic of Indonesia.MenurutMardiasmo (2011) local taxes are contributed obliged to regions that are owed by individuals or entities that are enforceable under the Act by not getting rewarded directly and used for the purposes for the area of welfare of the people. Tax Function No 2, namely:

a) Function Budgetair / financial, put as much money into state coffers, with ObjectiveTo finance state expenditures.

b) Regulerend Function / Set, taxes are used as a tool to regulate both the community both in

\subsection{Hotel tax} economic, social, and political with a specific purpose.

Mardiasmo (2011) defines that the local tax contribution to the region shall be payable by the individual or entity that is forced by law - laws, by not getting the rewards directly and used for the purposes for the area for - the welfare of the people. Law - Law No. 28 of 2009 states the tax is mandatory contribution to the region that are owed by individuals or entities that are enforceable under the Act, by not getting the rewards directly and used for the purposes of Regions for the greatest prosperity of the people.

Hotel tax subject is an individual or entity may be subject to local taxes. In connection with the hotel tax is a tax subject Hotel is the individual or entity that made the payment to the hotel (Prakosa, 2005). While that is a taxpayer is an individual or entity in accordance with the provisions of the legislation of regional tax required to make payments of tax payable, including tax collector or cutting certain taxes. Thus, the meaning of the taxpayer for the hotel tax is the person or entity paying for the service hotel and hotelier

Object hotel tax the services provided by the hotel with payment, including:

a. The lodging facilities or short stay facilities;

b. Service as a supplement lodging facilities or short stay to give comfort and convenience;

c. Olehraga and entertainment facilities provided exclusively for hotel guests, not for the public;

d. Room rental services for meetings or other activities at the hotel.

While that does not include the hotel tax objects are:

1) Rental house or rooms, apartments and / or other residence that does not blend with the hotel;

2) Services live in dormitories, and boarding;

3) Sports and entertainment facility that is provided in the dipergunakanoleh non-residents with payment;

4) Shops, offices, banks, salons used by the public in the hotel;

5) Travel services organized by the hotel and can be utilized by the public. 


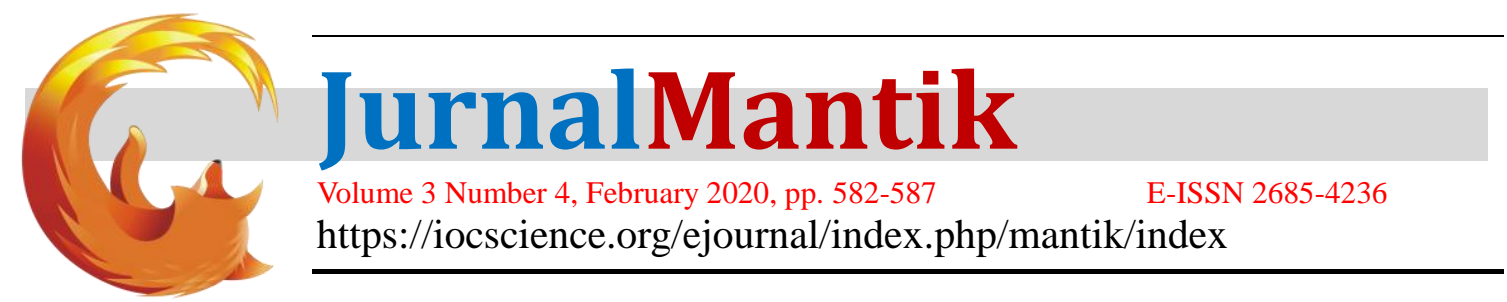

\section{Research Method}

This study uses a quantitative approach with descriptive methods. Descriptive quantitative research is one kind of research that aims to describe a systematic, factual, and accurate about the facts and the nature of specific populations, or try to describe the phenomenon in detail (Kuncoro, 2009). The area under the rules of Banyuwangi No. 2 of 2011 on Local Taxes and Banyuwangi Regent Regulation No. 19 Year 2018 on Amendment Banyuwangi regent Regulation No. 6 of 2018 on Guidelines for the Implementation of Technical Tax Collection hotel, said hotel tax is a tax on hotel dosediakan services. Definitions hotel are: fasiitas lodging service provider / resort including other related services levied which includes motels, inns, tourist huts,

Data is a collection of facts or reality would be credible so that it can be used to draw a conclusion. The availability of data is an absolute must be met in a scientific study. What types of data should be tailored to the needs in a study (Sugiyono, 2009). This study uses primary data and sekunde. This study uses primary data that provide questionnaires and interviews to the owner of the boarding and boarding BAPENDA as tax collector, while secondary data in this study is data taken from data published in the form of economic growth data, data on the number of boarding in Banyuwangi.

Based Banyuwangi Regency Regulation No. 2 of 2011 on local taxes, hotel rates are set at $10 \%$. Potential hotel tax can be defined as the ability, strength or power generating tax revenues hotel. To calculate the potential of the hotel used the following formula (Prakosa, 2005):

$\mathrm{PPH}=(\mathrm{Y} x$ Tax Rate Hotel $)$

$\mathrm{Y}=(\mathrm{R} \times \mathrm{D} \times \mathrm{H}) \times \mathrm{Pr}$

Information:

$\mathrm{R}=$ Number of Rooms

$\mathrm{D}=$ Number of days

$\mathrm{T}=$ Occupancy

$\operatorname{Pr}=$ the average room price

Based on data from BadanPendapatanDaerah (BAPENDA) BanyuwangiReagancynumber in banyuwangi boarding house in 2018 was 44 spread over several 4 sub-districts tile, District Banyuwangi, District and Sub-District GambiranGiri. Samples of this research is to collect data on three houses in each district Kost mentioned above, Information boarding name disguised as requested by the taxpayer rented house.

\section{Results and Discussion}

Following the calculation of the tax potential of boarding houses in each district: SubdistrictGenteng

\begin{tabular}{|l|l|c|c|r|}
\hline No. & Boarding House name & Rates average & Revenue / Month & Tax Boarding House \\
\hline 1 & Kost VA & $\operatorname{Rp~766~667~}$ & $\mathrm{Rp} \mathrm{23.306.667}$ & $\mathrm{Rp} \mathrm{27.968.000}$ \\
\hline 2 & Boarding House GA & $\operatorname{Rp~350.000~}$ & $\mathrm{Rp} \mathrm{9.471.000}$ & $\mathrm{Rp} \mathrm{11.365.200}$ \\
\hline 3 & Boarding House AY & $\mathrm{Rp} \mathrm{675,000}$ & $\mathrm{Rp} \mathrm{8.775.000}$ & $\mathrm{Rp} \mathrm{10.530.000}$ \\
\hline
\end{tabular}

Sub District Banyuwangi

\begin{tabular}{|c|c|c|c|c|}
\hline No. & Boarding House name & Rates Avg & Revenue / Month & Tax Boarding House \\
\hline 1 & Kost MJ & $\mathrm{Rp} 750.000$ & $\begin{array}{ll}\mathrm{Rp} & 13.387 .500 \\
\end{array}$ & $\begin{array}{ll}\mathrm{Rp} & 16.065 .000 \\
\end{array}$ \\
\hline 2 & Boarding House AM & Rp 700,000 & 210.000 .000 & 252.000 .000 \\
\hline 3 & Boarding House DP & Rp 550.000 & 297.000 .000 & 356.400 .000 \\
\hline
\end{tabular}

SubdistrictGambiran

\begin{tabular}{|l|l|l|ll|lc|}
\hline No. & Boarding House name & \multicolumn{2}{|l|}{ Rates Avg } & \multicolumn{2}{l|}{ Revenue / Month } & \multicolumn{2}{l|}{ Tax Boarding House } \\
\hline 1 & Kost MLJ & $\mathrm{Rp} \mathrm{300.000}$ & $\mathrm{Rp}$ & 2.880 .000 & $\mathrm{Rp}$ & 3.456 .000 \\
\hline 2 & Kost TY & $\mathrm{Rp} \mathrm{300.000}$ & $\mathrm{Rp}$ & 3.600 .000 & $\mathrm{Rp}$ & 4.320 .000 \\
\hline 3 & Boarding House DW & $\mathrm{Rp} \mathrm{350.000}$ & $\mathrm{Rp}$ & 2.450 .000 & $\mathrm{Rp}$ & 2.940 .000 \\
\hline
\end{tabular}




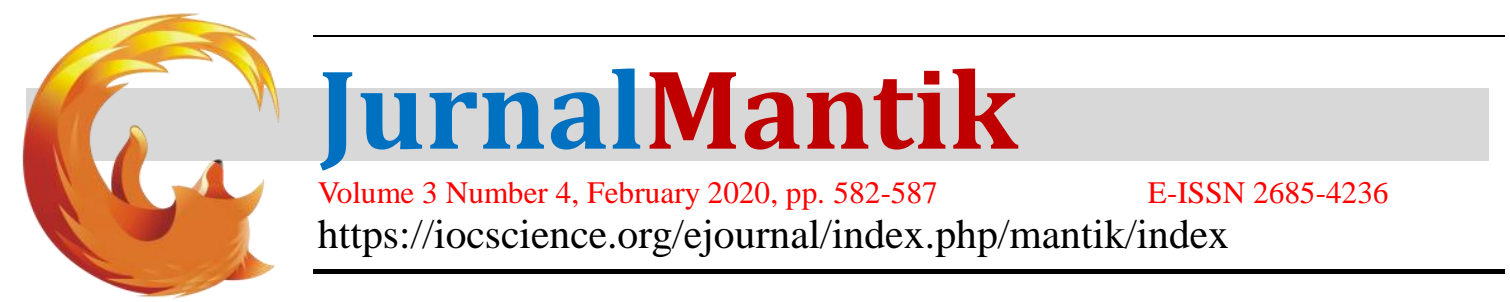

SubdistrictGiri

\begin{tabular}{|l|l|c|l|l|}
\hline No. & Boarding House name & Rates Avg & Revenue / Month & Tax Boarding House \\
\hline 1 & DJ Kost & Rp 1.000.000 & Rp20,000,000 & Rp24,000,000 \\
\hline 2 & home RTK & $\operatorname{Rp~} 625.000$ & Rp7.259.375 & Rp8.711.250 \\
\hline
\end{tabular}

Based on the calculations above, the tax potential Kost in Banyuwangi is Rp717,755,450.00, while the results obtained from the 11 boarding houses are made in the sampling in this study, from a total of 44 home Kost. While Kost Taxation is part of the hotel tax by the population as follows:

\begin{tabular}{|l|l|c|}
\hline No. & Classification Taxpayers & amount \\
\hline $\mathbf{1}$ & Hotel Melati 1 & 48 \\
\hline $\mathbf{2}$ & Hotel Melati 2 & 20 \\
\hline $\mathbf{3}$ & Hotel Melati 3 & 14 \\
\hline $\mathbf{4}$ & Penginapan & 6 \\
\hline $\mathbf{5}$ & Boarding house & 44 \\
\hline $\mathbf{6}$ & Villa & 4 \\
\hline $\mathbf{7}$ & Wisma & 2 \\
\hline \multicolumn{2}{|l|}{ Total } & 138 \\
\hline
\end{tabular}

Source: BapendaBanyuwangi (2018)

The above table outlines the number of hotel tax in Banyuwangi number 138, with the classification of hotels, lodging and Kost. The results of calculation of tax potential Rp717,755,450.00 a boarding house, while the number of these samples 10 of the population recorded in the boarding house Bapenda, while tax Boarding House part of the hotel tax, the target set in 2018, which amounted to Rp 7,000,000,000, and exceeds the realized in 2018 which amounted to $\operatorname{Rp} 6,898,991,797$. While the boarding house were examined in this study only $8 \%$ of the total number of taxpayers Hotel. This indicates that tax revenues, especially tax Hotel boarding house is still not optimal, there is still potential tax revenue is lost over boarding houses,

\section{Tax Revenue Optimization Strategies Boarding House}

Regency Government Strategies that can be implemented to increase the contribution of Regional Tax revenue are pursued through intensification and extension strategies, which include:

a) Revenue Board of Banyuwangi Regency should be sustained attempt within a certain time to check the data of House boarding tax and potential tax object Home boarding house on the field, so that the object data of boarding house tax will always be updated and could be a material consideration in the determination of strategies reception house boarding optimally, such as the research wulandari (2016) need to be reviewed on a boarding house which has rooms less than 10 but has luxury amenities, so that the rate per month is high, but not taxed boarding houses, due to hit PERDA (Local Government Regulation).

b) The need for intensive socialization on the implementation of a boarding house tax to tax officers, management of hotel/lodging/boarding house, and the general public. Socialization can be done by providing counseling, distributing flyers or newsletters, and went directly object boarding house. With their intensive socialization, is expected to create awareness in the implementation of a boarding house tax (Morong, 2016)

c) The need to involve other agencies in the implementation of the boarding house tax, for example by involving the sub-district and village where the boarding house is located. So that the subdistrict and village can participate in monitoring the boarding house tax objects that exist in the region.

d) Giving administrative sanctions (fines) and moral (social punishment) for taxpayers who do not comply with the tax rules of the hotel. Instead, reward taxpayers who have complied with the boarding house tax rules, so that taxpayers would feel proud to be a compulsory levy obedient for their reward that has been given to him.

e) The existence of boarding house online tax payments innovation, making it easier for taxpayers to meet the tax liability owed. With the online tax payment services, is expected to reduce the level of fraud committed either by the taxpayer or by the apparatus / taxman.

f) Implementation of potential boarding house tax mapping was able to provide a more accurate picture of the potential tax revenue boarding houses, so there should be follow-up surveys 


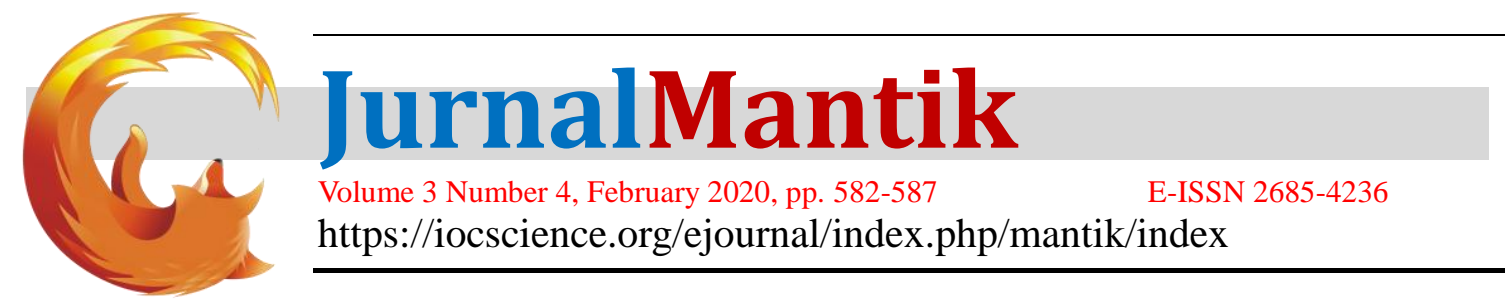

related to mapping of taxes and levies from other sectors, such as research conducted by Puspita and Wicaksono (2019) where mapping calculations tax potential restaurant can provide information on local government services targeting local taxes.

\section{Conclussion}

a) Based on information from four sub-districts can be concluded that the number of potential boarding house tax in Banyuwangi amounted IDR 717,755,450.00. Based on data from the target and the realization in 2018 obtained the hotel tax target is IDR 1.84 billion, and the realization of IDR 3.368.454.736 This indicates that tax revenue in Banyuwangi not maximized.

b) The strategy needs to be done by the local government to increase local revenue through optimizing the intensification tax collection area, strengthening the voting process, increase surveillance, improve administrative efficiency and reduce the cost of collection, This can be done by increasing coordination with related institutions in the region.

\section{Reference}

[1] Davey, K.J, 1988. PembiayaanPemerintahDaerah. Jakarta: PT. GramediaPustakaUtama

[2] Haryono, dkk. AnalisisPengelolaanPajakRumah Kos Di Kota Palopo. Government: JurnalllmuPemerintahan. Volume 6, Nomor 2, Juli 2013 (111-116). ISSN 1979-5645

[3] Kuncoro, Mudrajad. 2009. MetodeRisetuntukBisnis dan Ekonomi. Edisi 3. PenerbitErlangga: Jakarta

[4] Mardiasmo. 2011. Perpajakan. EdisiRevisi. Andi Offset, Yogyakarta.

[5] PemerintahKabupaten Banyuwangi.2011. PeraturanDaerahKabupaten Banyuwangi nomor 2 tahun 2011 tentangpajakdaerah.

[6] PemerintahRepublik Indonesia.2009. Undang-Undangnomor 28 tahun 2009 tentangpajakdaerah dan retribusidaerah.

[7] PemerintahKabupaten Banyuwangi.2016. PeraturanBupatiKabupaten Banyuwangi nomor 81 tahun 2016 tentangpembayaran dan pelaporanpajakparkir, pajakhotel, pajakrestoran dan pajakhiburansecaraelektronik

[8] PeraturanBupati Banyuwangi Nomor 19 Tahun 2018 TentangPerubahanAtasPeraturanBupati Banyuwangi Nomor 6 Tahun 2018 TentangPedomanTeknisPelaksanaanPemungutanPajakHotel

[9] Prakosa (2005), Pajak dan RetribusiDerah, Yogyakarta. UII Press

[10] Puspita, Yeni dan Galih Wicaksono. 2019. TheAnalysis Of Potential Restaurant Tax Revenue In Banyuwangi Regency. Vol 1 No 1 (2018): The Changing Course of Policy Failures and Policy Success: Sustaining Effective Policy in The ContemporaryGovernance Challenge

[11] Morong Christine. AnalisisPotensiPajakRumahKost Di Kota Tomohon. Jurnal Emba. Vol.4 No.2 Juni 2016, Hal. 273-285

[12] Sugiyono. (2009). MetodePenelitianBisnis (PendekatanKuantitatif, Kualitatif, dan R\&D). Bandung: Alfabeta

[13] Sukirno, Sadono, 2006, EkonomiPembangunan, Jakarta:Kencana.

[14] Tampubolon, Manahan, 2005, ManajemenKeuangan, EdisiPertama, Jakarta: GhaliaIndonesia

[15] Undang-UndangNomor 28 Tahun 2009 tentangPajakDaerah dan RetribusiDaerah

[16] Wulandari A. ProsidingSeminarNasionalPoliteknikNegeri ASBIS 2016. PoliteknikNegeri Banjarmasin. PotensiPajakRumah Kos SebagaiUpayaMeningkatkanPajakDaerahDalamPendapatanAsliDaerah Di Kota Banjarmasin.. ISSN: 2541-6014 